\title{
Synthesis and Characterization of Nano Silver for Different Temperatures and their Antimicrobial Activity
}

\author{
R. Sathiya priya ${ }^{1 *}$, D. Geetha ${ }^{2}$, P.S. Ramesh ${ }^{3}$ and V. Aroulmoji ${ }^{1}$ \\ ${ }_{1}^{1}$ Department of Physics \& Center for Research \& Development, Mahendra Engineering College, Namakkal-637503. \\ ${ }^{2}$ Department of Physics, Annamalai University, Annamalai Nagar- 608 002, Tamil Nadu, India. \\ 3 Physics Wing DDE, Annamalai University, Annamalai Nagar 608002, Tamil Nadu, India.
}

\begin{abstract}
Silver nanoparticles were synthesized at four different calcinations temperature viz., $150^{\circ} \mathrm{C}, 200^{\circ} \mathrm{C}, 250^{\circ} \mathrm{C}$ and $300^{\circ} \mathrm{C}$ by chemical reduction method. Silver nitrate was taken as precursor and sodium citrate as a reducing agent. The prepared silver nanoparticles were identified by UV-Vis absorption spectroscopy. Structural, morphological and size of the synthesized nanoparticles were characterized by XRD, SEM/EDS and particle analysis showed that the nano silver (Ag) samples are spherical with particle sizes of $0-95 \mathrm{~nm}$ by using particles size analyzer. Also we confirmed that the size of the silver nanoparticles was affected by the calcinations temperature. Antimicrobial activity of silver nanoparticles is important to control conventional antimicrobial agents. Bacterial and fungal contamination is a serious problem. This work evaluates the potential of nano silver to remove bacterial and fungal contaminants. The Experiment involved with three different bacteria's viz., Escherichia coli sp., Pseudomonas sp., and streptococcus sp., in MHA medium and three different fungus viz., Aspergillus sp., Pencilluim sp., Rhizopus sp., in SDA medium. The results show that nano silver has a good potential for removing of the bacterial and fungal contaminants in human.
\end{abstract}

KEYWORDS: Nanostructures, Chemical synthesis and Anti- microbial activity

(C) 2017 mahendrapublications.com, All rights reserved

\section{INTRODUCTION}

Inorganic nanoparticles, whose structures exhibit significantly novel and improved physical, chemical, and biological properties, phenomena and functionality due to their nanoscale size, have elicited must interest. Nano structural materials are attracting a great deal of attention because of their potential for achieving specific processes and selectivity especially in biological and pharmaceutical applications [1]. Among inorganic anti-microbial agents, silver has been employed most extensively to fight infections and control spoilage. The antibacterial and antifungal action of silver, silver ions, and silver compounds have been thoroughly investigated my many researchers. The antimicrobial property of silver has been investigated and employed more extensively than any other inorganic antibacterial agent [2]. Toxicity of silver ion and its compounds towards microbes is well established and this property was used in wound dressings, silver loaded zeolites etc., because of its higher stability, stronger antibacterial activity [3]. In particular, because of the recent advances in research on metal nanoparticles, Ag-Nps have received special attention as a possible antimicrobial agent [4-9]. It has been known that silver and its compounds have strong inhibitory and bactericidal effects as well as a broad spectrum of antimicrobial activities for bacteria, fungi, and virus since ancient times. Silver is a nontoxic, safe inorganic antibacterial agent used for centuries and is capable of killing about 650 types of diseases causing microorganisms [10]. An opportunistic fungal strain has increased dramatically [11-13]. Fungi also cause a number of plant and animal diseases: in humans, ringworm, athlete's foot, and several more serious diseases are caused by fungi, because fungi are more chemically and genetically similar to animals than other organisms, this makes fungal diseases very difficult to treat. Different types of nanomaterials like copper, zinc, titanium, magnesium, gold, alginate and silver have been developed but silver nanoparticles (Nano-Ag) have proved to be most effective as they exhibit potent antimicrobial efficacy against bacteria, viruses and eukaryotic micro-organisms [14-17]. The use of nano-sized silver particles are, as they are antimicrobial agents become more common as technological advances, make their production more economical. Silver may be less toxic to humans and animals than synthetic fungicides. Antimicrobial activity of silver nanoparticles is gaining importance due its broad spectrum of targets in cell compared to conventional antimicrobial agents. Hence, Ag-Nps have been applied to a wide range of healthcare products, such as burn dressings, scaffold, water purification systems, and medical devices $[18,19]$.

\section{MATERIALS AND METHODS}

The chemicals used for the study are silver nitrate $\left(\mathrm{AgNO}_{3}\right)$, citrate of sodium was purchased from Hi-media, Pondicherry. Received chemicals were used as such;Deionized water was used throughout the study. Human pathogens viz., E.coli sp., Pseudomonas sp., Streptococcus sp., Similarly fungi viz., Aspergillus sp., Pencillium sp., Rhizopus sp., NA Broth, Muller Hinton Agar, SDA solution, silver nanoparticles are prepared by using chemical reduction method.

\subsection{Synthesis of silver nanoparticle}

Silver nanoparticles are prepared from the reduction of 
silver nitrate by sodium citrate. This process has been done in four different temperatures $150^{\circ} \mathrm{C}, 200^{\circ} \mathrm{C}, 250^{\circ} \mathrm{C}$ and $300^{\circ} \mathrm{C}$. $1 \mathrm{M}$ of silver nitrate was prepared by dissolving in de-ionized water. Similarly, $0.1 \mathrm{ml}$ of sodium citrate solution was prepared. The transparent colorless solution of silver nitrate solution was changed into pale white, when sodium citrate was added into it. The mixed solution was kept in a magnetic stirrer for 24 hours. After that, the precipitation was collected, filtered and washed several times using de-ionized water and ethanol. The precipitate was kept at four different temperatures viz., $150^{\circ} \mathrm{C}, 200^{\circ} \mathrm{C}$, $250^{\circ} \mathrm{C}$ and $300^{\circ} \mathrm{C}$ for $30,25,20$ and 15 minutes respectively. The colour of the prepared samples was changed into pale brown (which is the indication of Nano silver).

\section{CHARACTERIZATIONS}

Ultra-Violet-Visible Spectroscopy (UV-Vis) was performed in a Shimadzu UV-1650PC Spectrophotometer. To determine the crystalline structure X-ray diffraction (XRD) is used and the data were obtained using a XPERT-PRO diffractometer. The studies of morphology of nanoparticles were performed in JEOL-JSM-5610LV with INCA EDS by scanning electron microscopy (SEM). Particle analyzer was done to measure the particle size using U2475ES Nano. Ultra.

\section{RESULTS AND DISCUSSION 4.1. Optical Studies}

UV-Vis spectroscopy is one of the most widely used techniques for structural characterization of silver nanoparticles. The absorption spectrum (Fig. 1) of the pale brown silver colloids prepared by chemical reduction showed a surface Plasmon absorption band with a maximum of $425 \mathrm{~nm}, 420 \mathrm{~nm}, 414 \mathrm{~nm}$ and $402 \mathrm{~nm}$ for $150^{\circ} \mathrm{C}, 200^{\circ} \mathrm{C}, 250^{\circ} \mathrm{C}$ and $300^{\circ} \mathrm{C}$ respectively is the indication the presence of spherical or roughly spherical silver nanoparticles, UV-Vis absorption spectrum reveals that, the position and shape of the Plasmon absorption depends on the particle size, shape and the dielectric constant of the surrounding medium. It may be observed that surface Plasmon absorption maximum is at $425 \mathrm{~nm}$ and $420 \mathrm{~nm}$ for $150^{\circ} \mathrm{C}$ and $200^{\circ} \mathrm{C}$ but at the temperatures $250^{\circ} \mathrm{C}$ and $300^{\circ} \mathrm{C}$ the absorption maximum at $414 \mathrm{~nm}$ and $402 \mathrm{~nm}$. From the figure 1 it may be observed that the shift is to lower wavelength with two temperatures $\left(250^{\circ} \mathrm{C}\right.$ and $300^{\circ} \mathrm{C}$ ). The spectrum shows a smooth variation.

\subsection{X-ray Diffraction Studies}

The formation of silver nanoparticles in the chemical reduction method has been demonstrated by X-ray diffraction studies. XRD data indicate well-defined characteristic patterns of silver nanoparticles present in the sample [20]. The observed diffraction peaks are found at 38.1, 44.26, 64.50 and 77.42 and assigned to (111), (200), (220), and (311) planed of free silver particles (Fig 2). The crystallinity of the silver nano-clusters was established by performing the powder X-ray diffraction, the data of which was collected for four different temperatures $\left(150^{\circ} \mathrm{C}, 200^{\circ} \mathrm{C}, 250^{\circ} \mathrm{C}\right.$ and $\left.300^{\circ} \mathrm{C}\right)$. The four diffraction peaks obtained at an angle 39.98, 44.28, 64.46 and 77.32 respectively, could be completely attributed to the facecentered cubic crystalline nature of the sample. As shown in the figure, the highly intense diffraction peak was located at $2 \theta=39.98$. This peak is from the (111) plane of the Face Centered Cubic silver. Referring to the above pattern, the lattice constant for the $\mathrm{Ag}$ was estimated to be $\mathrm{a}=4.0875 \AA$ which was consistent with the reported values $(\mathrm{a}=4.0875 \AA)$; JCPDS File no (04-0783). The (200), (220) and (311) peaks are less intense. So, in the case, it might conclude that the Nano-assemblies were mainly composed of (111) lattice planes.

\subsection{SEM Analysis}

The scanning electron microscopy (SEM) image of the synthesized silver is presented in Fig.3 which indicated more or less spherical. The average size of these particles is approximately 38 for $150^{\circ} \mathrm{C}, 34$ for $200^{\circ} \mathrm{C}, 29$ for $250^{\circ} \mathrm{C}$ and 20 for $300^{\circ} \mathrm{C}$. In comparison with particle size obtained in various temperatures (Table 1 ) the mean diameter increase significantly at two different temperatures namely $200^{\circ} \mathrm{C}$ and $300^{\circ} \mathrm{C}$. At the same time the shifting of surface Plasmon absorption maximum from $425 \mathrm{~nm}$ to $420 \mathrm{~nm}$ and $414 \mathrm{~nm}$ to $402 \mathrm{~nm}$ could be due to the difference in particles shape and size, there is a decrease in absorption indicating a little aggregation of silver nanoparticles. The SEM images for the samples, prepared at $200^{\circ} \mathrm{C}$ and $300^{\circ} \mathrm{C}$ are most interesting because of the equal proportion of spherical nanoparticles and flat nano disks prevailing at this temperature. It is to be noted that the width of individual nano disk is in the range 40-95 $\mathrm{nm}$. The spherical nano globules have dimensions as large as $95 \mathrm{~nm}$, but are compositions of smaller spherical nanoparticles, which become as small as $29 \mathrm{~nm}$. Fig.3. (a, b, c, d) depicts the SEM images of samples obtained from the powdered silver nanoparticles prepared at $150^{\circ} \mathrm{C}, 200^{\circ} \mathrm{C}$, $250^{\circ} \mathrm{C}$ and $300^{\circ} \mathrm{C}$.

Fig.3 (a) is the SEM image of sample prepared from the Ag colloidal solution of $150^{\circ} \mathrm{C}$ that shows the existence of very few spherical nanoparticles. At $200^{\circ} \mathrm{C}$ the SEM feature [Fig. 3(b)] clearly reveals the globular nano clusters in the diameter range $20 \mathrm{~nm}$. This is the dominant morphology at this temperature, but a small number of stacked nano-disks could also be seen. Fig.3 (c) is the SEM images of the samples corresponding to $250^{\circ} \mathrm{C}$ colloidal silver solutions. In this temperature also the predominant morphology is the spherical nano aggregates but the proportion of nanodisks is higher compared to the $200^{\circ} \mathrm{C}$. 
Table 1 Particle sizes from XRD, Particle size analyzer and surface plasmon absorption maximum silver nanoparticles at different temperature by salt reduction method.

\begin{tabular}{|c|c|c|c|}
\hline Temperature & $\begin{array}{c}\text { UV-VIS } \\
\text { wavelength }\end{array}$ & $\begin{array}{c}\text { X-Ray Diffraction } \\
\text { Particle size }\end{array}$ & $\begin{array}{c}\text { Particle Analyzer } \\
\text { Particle size }\end{array}$ \\
\hline $\mathbf{1 5 0}^{\mathbf{C}} \mathbf{C}$ & $425 \mathrm{~nm}$ & $38 \mathrm{~nm}$ & $95 \mathrm{~nm}$ \\
\hline $\mathbf{2 0 0}^{\mathbf{C}} \mathbf{C}$ & $420 \mathrm{~nm}$ & $34 \mathrm{~nm}$ & $90 \mathrm{~nm}$ \\
\hline $\mathbf{2 5 0}^{\mathbf{C}} \mathbf{C}$ & $414 \mathrm{~nm}$ & $29 \mathrm{~nm}$ & $75 \mathrm{~nm}$ \\
\hline $\mathbf{3 0 0}^{\mathbf{C}} \mathbf{C}$ & $402 \mathrm{~nm}$ & $20 \mathrm{~nm}$ & $65 \mathrm{~nm}$ \\
\hline
\end{tabular}

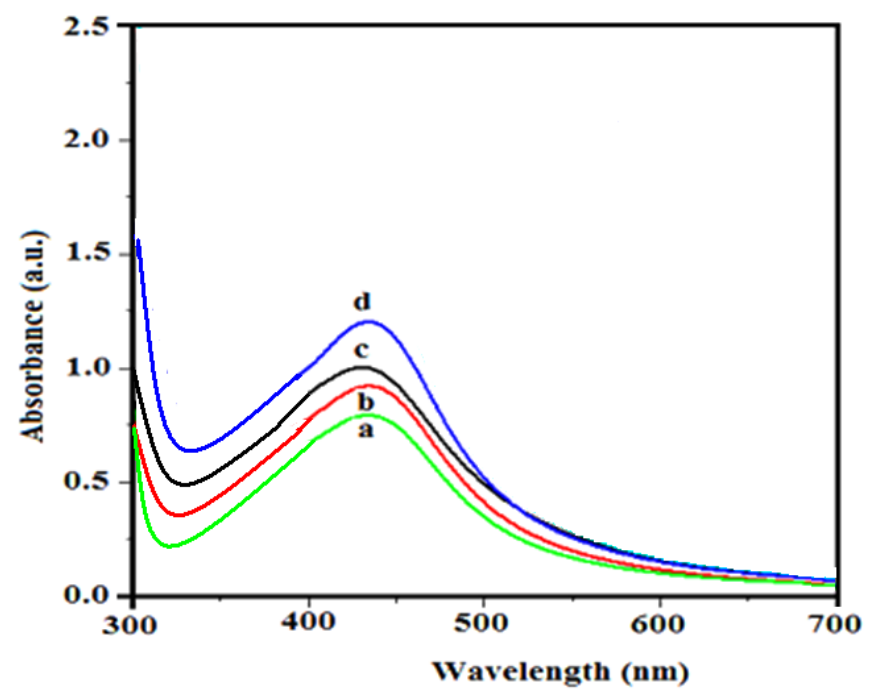

Fig. 1.UV-Visible spectrum of silver nanoparticles a) $\left.425 \mathrm{~nm} \mathrm{at} 150^{\circ} \mathrm{C}, \mathrm{b}\right) 420 \mathrm{~nm}$ at $200^{\circ} \mathrm{C}$, c) $414 \mathrm{~nm} \mathrm{at} 250^{\circ} \mathrm{C}$ and d) $402 \mathrm{~nm}$ at $300^{\circ} \mathrm{C}$

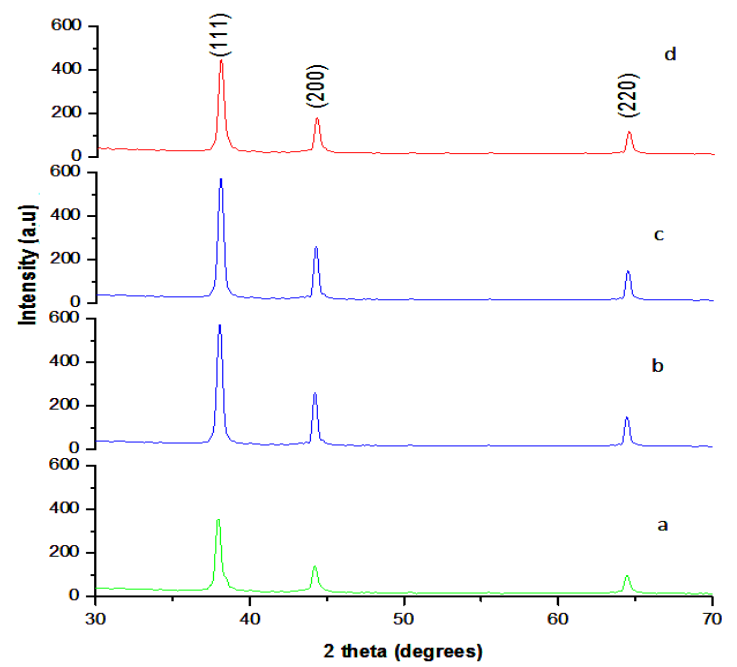

Fig.2. X-ray diffraction spectrum of silver nanoparticles at150 $\left.\left.{ }^{\circ} \mathrm{C}, \mathrm{b}\right) 200^{\circ} \mathrm{C}, \mathrm{c}\right) 250^{\circ} \mathrm{C}$ and d) $300^{\circ} \mathrm{C}$ 


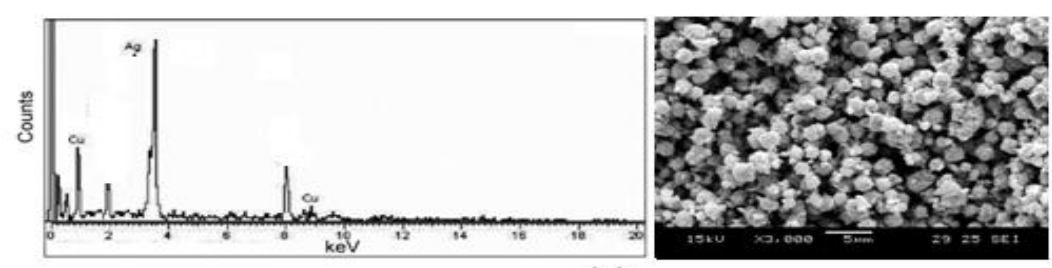

(a)

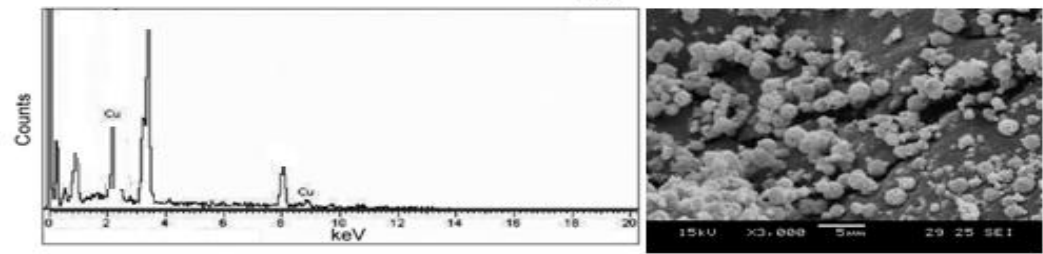

(b)
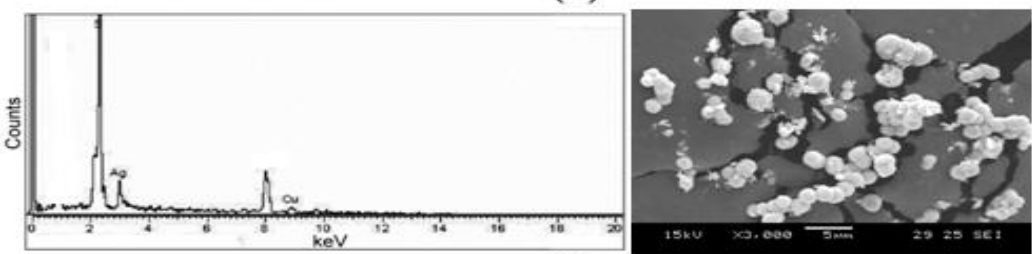

(c)

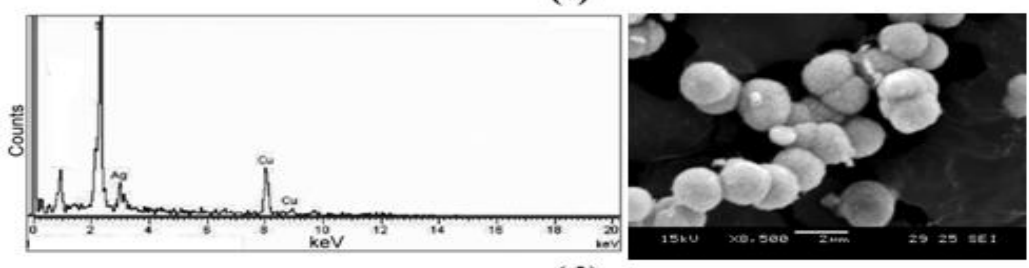

(d)

Fig. 3.SEM photographs of silver nanoparticles with EDS at different temperature (a) $150^{\circ} \mathrm{C}$ (b) $200^{\circ} \mathrm{C}$ (c) $250^{\circ} \mathrm{C}$ (d) $300^{\circ} \mathrm{C}$

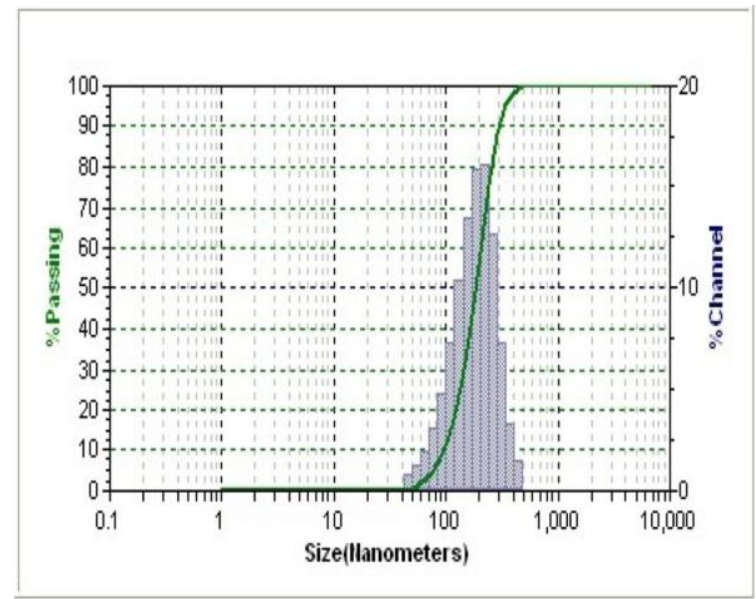

(a)

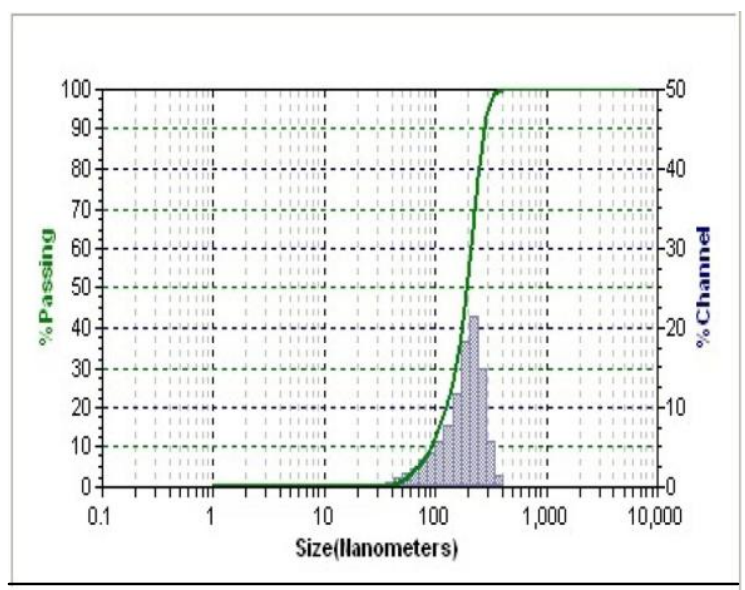

(b) 


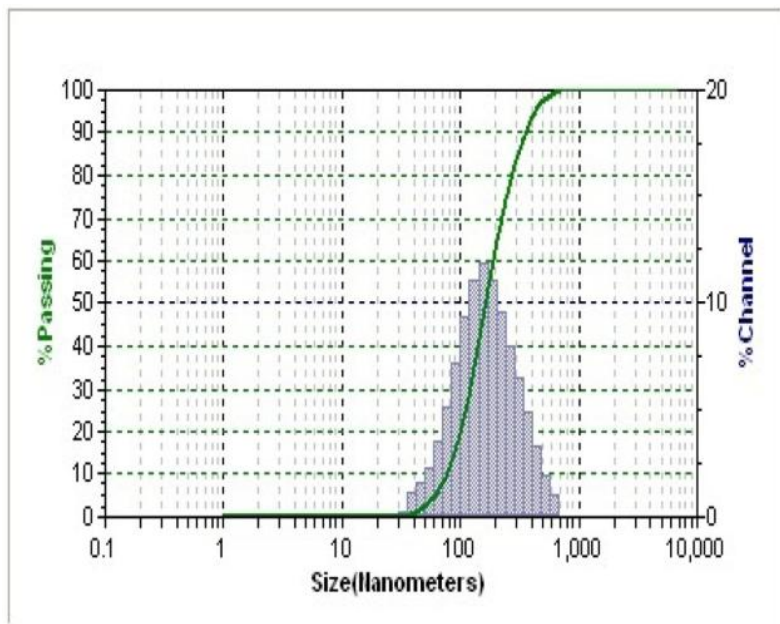

(c)

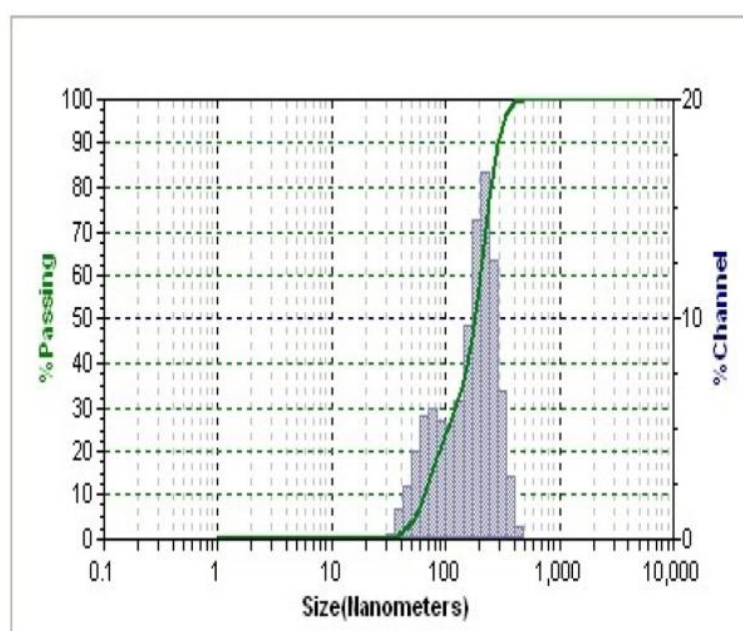

(d)

Fig .4.Shows the particle size analyzer spectrum a) $\left.\left.150^{\circ} \mathrm{C}, \mathrm{b}\right) 200^{\circ} \mathrm{C}, \mathrm{c}\right) 250^{\circ} \mathrm{C}$, d) $300^{\circ} \mathrm{C}$

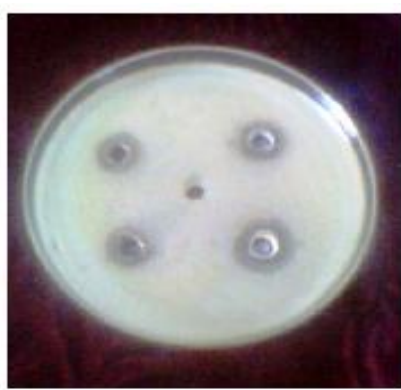

5 a

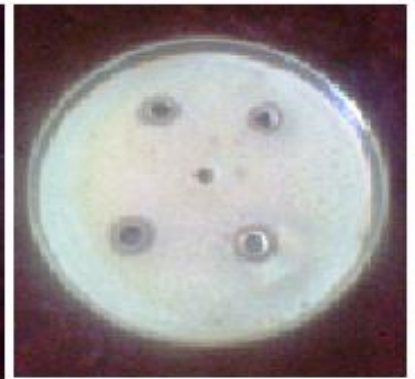

$5 \mathbf{b}$

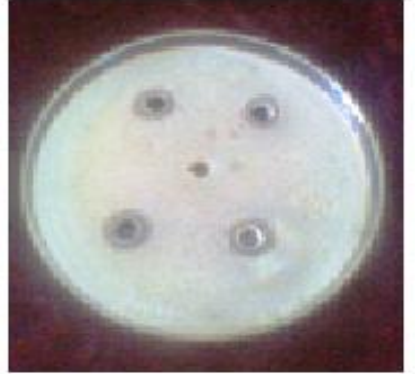

$5 c$

Fig .5.shows the antimicrobial activity of silver nanoparticles prepared at $150^{\circ} \mathrm{C}, 200^{\circ} \mathrm{C}, 250^{\circ} \mathrm{C}$, and $300^{\circ} \mathrm{C}$ on bacteria such as a) E.coli sp. b) Pseudomonas sp. and c) Streptococcus sp.

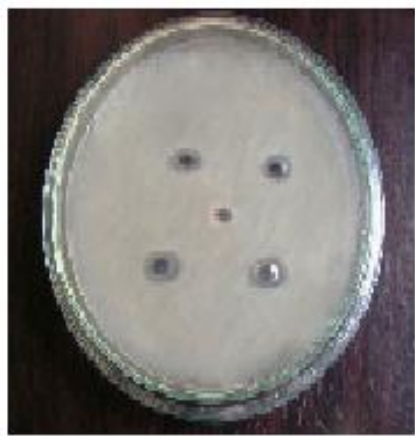

6a

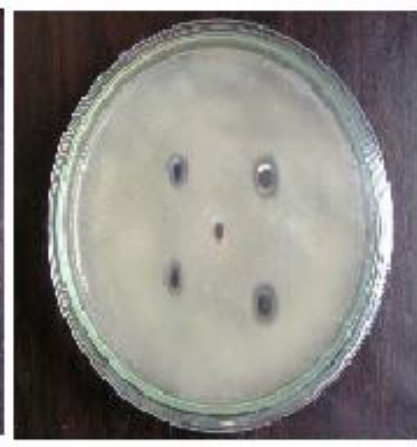

6b

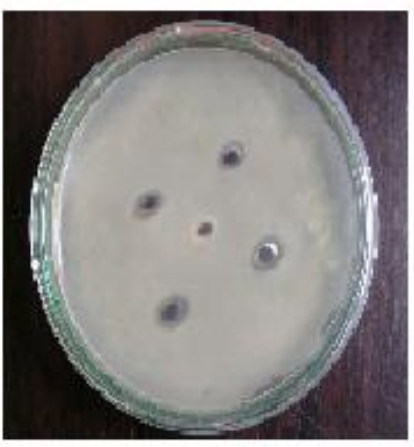

$6 \mathrm{c}$

Fig. 6.Shows the antimicrobial activity of silver nanoparticles prepared at $150^{\circ} \mathrm{C}, 200^{\circ} \mathrm{C}, 250^{\circ} \mathrm{C}$, and $300^{\circ} \mathrm{C}$ on fungus such as a) Aspergillus sp. b) Pencillium sp. c) Rhizopus sp. 
Table 2 Zone of inhibition ( $\mathrm{mm}$ ) of silver nanoparticles sols prepared at different conditions against test strain (Bacteria)

\begin{tabular}{|c|c|c|c|c|}
\hline Bacteria & $\mathbf{1 5 0}^{\circ} \mathbf{C} / \mathbf{9 5}$ & $\mathbf{2 0 0}^{\circ} \mathbf{C} / \mathbf{9 0}$ & $\mathbf{2 5 0}^{\circ} \mathbf{C} / \mathbf{7 5}$ & $\mathbf{3 0 0}^{\circ} \mathbf{C} / \mathbf{6 5}$ \\
\hline E.coli sp. & $16 \mathrm{~mm}$ & $17 \mathrm{~mm}$ & $21 \mathrm{~mm}$ & $22 \mathrm{~mm}$ \\
\hline Pseudomonas sp. & $10 \mathrm{~mm}$ & $11 \mathrm{~mm}$ & $12 \mathrm{~mm}$ & $15 \mathrm{~mm}$ \\
\hline Streptococcus sp. & $9 \mathrm{~mm}$ & $10 \mathrm{~mm}$ & $11 \mathrm{~mm}$ & $13 \mathrm{~mm}$ \\
\hline
\end{tabular}

Table 3 Zone of inhibition ( $\mathrm{mm}$ ) of silver nanoparticles sols prepared at different conditions against test strain (Fungi)

\begin{tabular}{|c|c|c|c|c|}
\hline Fungus & $\mathbf{1 5 0}^{\circ} \mathbf{C} / \mathbf{9 5}$ & $\mathbf{2 0 0}^{\circ} \mathbf{C} / \mathbf{9 0}$ & $\mathbf{2 5 0}^{\circ} \mathbf{C} / \mathbf{7 5}$ & $\mathbf{3 0 0}^{\circ} \mathbf{C} / \mathbf{6 5}$ \\
\hline Aspergillus sp. & $9 \mathrm{~mm}$ & $10 \mathrm{~mm}$ & $11 \mathrm{~mm}$ & $12 \mathrm{~mm}$ \\
\hline Pencillium sp. & $10 \mathrm{~mm}$ & $11 \mathrm{~mm}$ & $12 \mathrm{~mm}$ & $13 \mathrm{~mm}$ \\
\hline Rhizopus sp. & $12 \mathrm{~mm}$ & $13 \mathrm{~mm}$ & $14 \mathrm{~mm}$ & $15 \mathrm{~mm}$ \\
\hline
\end{tabular}

\subsection{Particle size analyzer}

Laser diffraction particle size analyzer provides the detail about the particle nature, such as monodispersed, didispersed and poly-dispersed [21]. This investigation revealed that nanoparticles are in poly-dispersed mixture, with the various sized ranges from 60-100 nm. The obtained nano silver analysis with particle size analyzer, with various temperatures of $150^{\circ} \mathrm{C}, 200^{\circ} \mathrm{C}, 250^{\circ} \mathrm{C}$ and $300^{\circ} \mathrm{C}$ is showed in Fig. 4 Particle-size analysis reveals that the prepared nano silver has a diameter of 95. It is noteworthy that the diameter of the particles measured by particle-size analysis higher than the size estimated from XRD predominantly because of high swelling capacity of silver nanoparticles. Fig.4 showed the correlation between temperature and nano silver particle diameter. In varied temperatures of $150^{\circ} \mathrm{C}, 200^{\circ} \mathrm{C}, 250^{\circ} \mathrm{C}$ and $300^{\circ} \mathrm{C}$ they obtained nanosilver diameter were 95, 90, 75, and $65 \mathrm{~nm}$ respectively. These four points of temperature variations was chosen considering the boiling point of water as the solvent and the melting point $\left(444^{\circ} \mathrm{C}\right)$ of silver.

\subsection{Microbial Activity of Nanosilver}

Three micro-organisms were chosen as test strains; such as Escherichia coli sp., Pseudomonas sp., streptococcus sp. (bacteria) and Aspergillus sp., Pencillium sp., Rhizopus sp., (fungus). In view of the results, it appeared that all tested Ag nanoparticles are the most effective products against the tested bacterial and fungal strains. Finally, the antimicrobial susceptibility of $\mathrm{Ag}$ nanoparticles synthesized was investigated. The Kirby-Bauer diffusion method was used as antimicrobial susceptibility testing method. Disposable plates inoculated with the tested bacteria, and fungus at a concentration of $1 \mathrm{ml}$ solution was used for the tests. Zone of inhibition were obtained and measured after $24 \mathrm{hr}$. (bacteria) and $168 \mathrm{hr}$. (fungus) of incubation at $35^{\circ} \mathrm{C}$.

Fig. 5 shows plates to which a bacterial suspension was applied and Fig.6 shows the plates to which a fungus suspension was applied ( $1 \mathrm{ml}$ solution). The presence of nanoparticles at a certain level inhibited bacterial growth by more than $90 \%$. The diameter of inhibition zone (in millimeter) around the different silver nanoparticles sols against test strains are shown in Table .2 and 3.

Decrease in particle size of silver nanoparticles show a lower susceptibility. However, it is necessary to determine the minimum inhibitory concentration (MIC) of each sample. The silver sols were diluted with distilled water and applied on the bacteria incubated on the Miller Hinton Agar with the concentration of $1 \mathrm{ml}$. The minimum inhibitory concentration (MIC) was read after $24 \mathrm{hr}$. of incubation at $35^{\circ} \mathrm{C}$. Similarly the silver sols were applied on the fungus incubated on the Sabourauds Dextrose Agar with the concentration of $1 \mathrm{ml}$. The MIC was read after $168 \mathrm{hr}$. of incubation at $35^{\circ} \mathrm{C}$. Smaller silver nanoparticles synthesized using citrate of sodium has considerably shows the antimicrobial activity. This phenomenon is related to size of colloidal silver particles. Thus the $20 \mathrm{~nm}$ (XRD) silver nanoparticles showed the highest activity against bacteria and fungi.

Silver nanoparticles may attach to the surface of the cell membrane and disturb its power function such as permeability and respiration. It is reasonable to state that the binding of the particle to the bacteria depends on the surface area available for interaction. Smaller particles having the larger surface area available for interaction will give more bactericidal and fungicidal effect than the larger Ag nanoparticles.

\section{CONCLUSION}

Silver nanoparticles were synthesized using chemical reduction method at four different temperatures. UV-Vis spectra show the characteristic Plasmon absorption peak for silver nanoparticles ranging from 402 to $425 \mathrm{~nm}$. The XRD spectrum reveals the clear peaks at higher temperature $\left(300^{\circ} \mathrm{C}\right)$ with particles size of $20 \mathrm{~nm}$. The SEM/EDS of the samples shows the spherical morphology 
and confirmed the presence of elemental silver, no peaks of other impurity were detected, and SEM study revealed the temperature dependent morphological variation of the nanoparticles, at $200^{\circ} \mathrm{C}$ and $300^{\circ} \mathrm{C}$ temperatures only spherical morphology was observed, while at $150^{\circ} \mathrm{C}$ and $250^{\circ} \mathrm{C}$ disk morphology was appeared. Particles size analyzer (PSA) measurements showed that the silver nanoparticles form aggregates. Additionally, the antibacterial and antifungal activity of the nanoparticles dispersion was measured by Kirby-Baur method. The results of this study clearly demonstrated that the colloidal silver nanoparticles inhibited the growth and multiplication of the tested bacteria and fungi, including highly multi-resistant bacteria such as Escherichia coli sp., Pseudomonas sp., and streptococcus sp. and fungus viz., Aspergillus sp, Pencillium sp., and Rhizopus sp. Such high antimicrobial activity was observed at very small sized nano silver.

From the observed results, it may be concluded that, the nano silver fight against the microbes in the order of

(i) Bacteria: Ag Nps: E.Coli sp., > Pseudomonas sp., > Streptococcus sp.

(ii) Fungi: Ag Nps: Rhizopus sp., > Pencillium sp., > Aspergillus sp.

Hence, the E. coli (Bacteria) and Rhizopus sp., (Fungal) have more inhibition (or) highest zone of clearance.

\section{REFERENCES}

[1]. Brigger,I., Dubernet,C., Couvreur,P., 2002, Nanoparticles in cancer therapy and diagnosis, Adv. Drug Delivery 54631.

[2]. Franke, S., Grass, G., Nies, D.H., 2001, The product of the ybdE gene of the Escherichia coli chromosome is involved in detoxification of silver ions, Microbial 147 965-972.

[3]. Jo. J.K., Kim, B.H., Jung, G., 2009, Antifungal Activity of Silver Ions and Nanoparticles on Phytopathogenic Fungi, Plant 93 1037-1043.

[4]. Silver, S., 2003, Bacterial silver resistance: molecular biology and uses and misuses of silver compounds, FEMS. Microbiol. Rev 27 341-353.

[5]. Baker, C., Pradhan, A., Pakstis, L., Pochan, D.J., Shah, S.I., 2005, Synthesis and antibacterial properties of silver nanoparticles, J. Nanosci. Nanotechnol 5, 244-249.

[6]. Lee, B.U., Yun, S.H., Ji, J.H., Bae, G.N., 2008, Inactivation of S. epidermidis, B. subtilis, and E. coli bacteria bioaerosols deposited on a filter utilizing airborne silver nanoparticles, J. Microbiol. Biotechnol 18, 176-182.

[7]. Melaiye, A., Sun, Z., Hindi, K., Milsted, A., Ely, D., Reneker, D.H., Tessier, C.A., Youngs, W.Y., 2005, Silver(I)-imidazole cyclophane gem-diol complexes encapsulated by electrospun tecophilic nanofibers: formation of nanosilver particles and antimicrobial activity, J. Am.Chem. Soc 127 2285-91.

[8]. Sondi, I., Salopek-Sondi, B., 2004, Silver nanoparticles as antimicrobial agent: a case study on E. coli as a model for Gram-negative bacteria, J. Colloid Interface Sci, 275, 177-82.
[9]. Lok, C.N., Ho, C.M., Chen, R., He, Q.Y., Yu, W.Y., Sun, H., Tam, P.K., Chiu, J.F., Chen, C.M., 2006, Proteomic Analysis of the Mode of Antibacterial Action of Silver Nanoparticles, J. Proteome. Re, 5, 916-924.

[10]. Cho, K.H., Park, J.E., Osaka, J., Park, S.G., 2005.The study of antimicrobial activity and preservative effects of nanosilver ingredient. Electrochim Acta, 51, 956-960.

[11]. Denning, D.W., 1991, Epidemiology and pathogenesis of systemic fungal infections in the immunocompromised host, Journal of antimicrobial chemotherapy 28, 1-16.

[12]. Ellis, M., Richardson, M., De Pauw,B., 2000 Symposium on invasive fungal infections: epidemiology, Hospital medicine 61, 605-609.

[13]. Odds, F.C., Brown, A.J., Gow, N.A., 2003. Antifungal agents: mechanisms of action, Trends in microbiology, 11, 272-9.

[14]. Schabes-Retchkiman, P.S., Canizal, G., HerreraBecerra, R., Zorrilla, C., Liu, H.B., Ascencio, J.A., 2006, Biosynthesis and characterization of Ti/Ni bimetallic nanoparticles, Optical materials 29 95-99.

[15]. Gu, H., Ho, P.L., Tong, E., Wang, L., Xu, B., 2003. Presenting Vancomycin on Nanoparticles to Enhance Antimicrobial Activities, Nano letters 3, 1261-1263.

[16]. Ahmad, R., Shahverdi, Ali Fakhimi, Pharma Hamid, D., R.Shahverdi, 2007, Synthesis and effect of silver nanoparticles on the antibacterial activity of different antibiotics against Staphylococcus aureus and Escherichia coli, Nanomedicine: Nanotechnology, Biology and Medicine 3 168-171.

[17]. Gong, P., Li, H., He,X., Wang, K., Hu, J., Weihong Tan, Zhang, S., Yang, X., 2007, Preparation and antibacterial activity of Fe304@Ag nanoparticles, Nanotechnology 18604.

[18]. Thomas, V., Yallapu, M.M., Sreedhar, B., Bajpai, S.K., 2007, A versatile strategy to fabricate hydrogel-silver nanocomposites and investigation of their antimicrobial activity, J Colloid Interface Sci, 315 389-95.

[19]. Kim, S., Kim, H.J., 2006. Anti-bacterial performance of colloidal silver-treated laminate wood flooring, Int. Biodeterioration Biodegradation, 57, 155-162.

[20]. Sougata Sarkar, Atish.Dipankar Jana, Samir Kumar Samanta, Golam Mostafa, 2007, Facile synthesis of silver nano particles with highly efficient anti-microbial property, Polyhedron 26 4419-4426.

[21]. Sathiya Priya, R., Geetha, D,S Ramesh, P.S, 2016, Nanofabrication and characterization of silver nanostructure from Carica Papaya leaf extract and their antioxidant activity, Int.J.Adv.Sci.Eng, $3(2), 271-277$. 